\title{
Work in Hypoxic Conditions-Consensus Statement of the Medical Commission of the Union Internationale des Associations d'Alpinisme (UIAA MedCom)
} THOMAS KÜPPER ${ }^{1,2} *$, JIM S. MILLEDGE
JA, , DAVID HILLEBRANDT $^{2}$,
ULF GIESELER $^{9}$, RICHARD PULLAN $^{10}$ and VOLKER SCHÖFFL

${ }^{1}$ Institute of Occupational and Social Medicine, Rheinisch-Westfälische Technische Hochschule (RWTH) Aachen University, Pauwelsstrasse 30, D-52074 Aachen, Germany; ${ }^{2}$ Medical Commission of the Union Internationale des Associations d'Alpinisme (UIAA MedCom $), 3000$ Bern/Switzerland; ${ }^{3}$ University College of London, Department of Physiology, London, WC1E 6BT, UK; ${ }^{4}$ Emergency Medical Service and Helicopter Medical Service of the Region Vysocina, 58633 Jihlava Czechia; ${ }^{5}$ Anaesthesiology and Resuscitation Department, Jihlava Hospital, Vrchlickeho 59, 58633 Jihlava, Czechia; ${ }^{6}$ Medical Commission of the Czech Mountaineering Association, 16017 Prague 6 - Stiahov/Czech Republik; ${ }^{7}$ Department of Surgery, Kantonsspital Aarau, 5000 Aarau, Switzerland; ${ }^{8}$ Nepal International Clinic, GPO Box 3596, Laldurbarmarg 47, Kathmandu, Nepal; ${ }^{9}$ Department of Internal Medicine, Diakonissenkrankenhaus Speyer, 67346 Speyer, Germany; ${ }^{10}$ The Altitude Centre, London, WC2B 5SP, UK; ${ }^{11}$ Department of Sportorthopedics, Klinikum Bamberg, 96049 Bamberg, Germany; ${ }^{12}$ Department of Trauma Surgery, Friedrich Alexander University Erlangen-Nuremberg, 91054 Erlangen, Germany

Received 21 September 2009; in final form 1 December 2010; published online 25 March 2011

Objectives: The Commission gives recommendations on how to provide health and safety for employees in different kinds of low oxygen atmospheres. So far, no recommendations exist that take into account the several factors we have outlined in this report.

Methods: The health and safety recommendations of several countries were analysed for their strength and deficiencies. The scientific literature was checked (Medline, etc.) and evaluated for relevance of the topic. Typical situations of work in hypoxia were defined and their specific risks described. Specific recommendations are provided for any of these situations.

Results: We defined four main groups with some subgroups (main risk in brackets): short exposure (pressure change), limited exposure (acute altitude disease), expatriates (chronic altitude disease), and high-altitude populations (re-entry pulmonary oedema). For healthy unacclimatized persons, an acute but limited exposure down to $13 \% \mathrm{O}_{2}$ does not cause a health risk. Employees should be advised to leave hypoxic areas for any break, if possible. Detailed advice is given for any other situation and pre-existing diseases.

Conclusions: If the specific risk of the respective type of hypoxia is taken into account, a pragmatic approach to provide health and safety for employees is possible. In contrast to other occupational exposures, a repeated exposure as often as possible is of benefit as it causes partial acclimatization. The consensus statement was approved by written consent in lieu of a meeting in July 2009.

Keywords: fire protection; high altitude; hypoxia; travel; Union Internationale des Associations d'Alpinisme

\footnotetext{
*Author to whom correspondence should be addressed. Tel: +49-0-1520-1820256; fax: +49-0-241-8082587; e-mail: tkuepper@ukaachen.de
}

\section{INTRODUCTION}

The Union Internationale des Associations d'Alpinisme (UIAA) is the world umbrella organization 
for health and safety at altitude. Apart from pure technical aspects, expedition, doping, environmental protection, and others, which are all covered by specific commissions, the medical commission (UIAA MedCom) focuses on preventive aspects of high-altitude exposure. This traditionally includes the effects of hypoxia on humans. With more and more employees exposed to hypoxia in international business and others working in hypoxic rooms for fire protection or altitude training, the commission expanded its field to include occupational aspects of altitude or hypoxia exposure. In total, the UIAA represents 69 countries worldwide (delegates and corresponding members) with a total of 77 organizations, 37 of which have joined the medical commission (for details see www.theuiaa.org/ organization.html). The recommendations given by UIAA MedCom are regularly updated and based on consensus from the entire commission.

The recommendations are based on intensive literature research which include the most important subject matter:

1. The guidelines of those European countries (and USA), where hypoxic chambers are in industrial use. The list of countries was obtained by the manufacturers of such equipment.

2. A detailed research of international medical databases (e.g. Medline) with the following keywords: hypobaric hypoxia, isobaric hypoxia, altitude, disorders, occupational safety, acute mountain sickness (AMS), occupational health, occupational medicine, and altitude training.

All previous recommendations conducted by the UIAA MedCom, which are relevant to this topic, have been referenced. These international recommendations are supported by a detailed literature research, which is therefore indirectly included in this report. The literature research was performed in international literature databases (e.g. PubMed, DIMDI, etc.) with an extensive list of keywords [e.g. altitude, hypoxia, isobaric hypoxia, occupational medicine, aviation, passengers, AMS), high-altitude diseases, high-altitude pulmonary oedema (HAPE), chronic mountain sickness (CMS), Monge's disease, several keywords for pre-existing diseases, and many others). For older literature, the reference list of the papers as well as the personal literature knowledge of the specialists were used. As there is a total of $>1000$ papers, which are potentially of interest for the topic, the consensus group had to select those which were considered to be most important for the actual recommendation. It must be pointed out that this is not a pure physiological paper: the multitude and variability of influencing factors forces one to categorize these factors, which in consequence meant that not every detail can be discussed individually. Otherwise, the recommendation would be unmanageable. As most of the recent papers add only minimal and very detailed facts to older and wellestablished literature, the consensus group considered that it is fair to refer to the original (older) literature wherever possible. This also underscores that these respective statements are internationally well accepted.

There are no exact data available that how many employees are exposed to altitude or isobaric hypoxia, mainly because the group is extremely heterogeneous (mountain rescue, maintaining, service for tourists, mining, astronomers, mountain guides, pilots, people on business flights, coaches for altitude/hypoxia training, etc.). Küpper (2006) gives a survey of some data: there are $\sim 10000$ members of the German mountain rescue organizations, their number in Europe exceeds 30 000. The alpine clubs of Europe operate $>2100$ huts in the Alps. With an estimated average of at least four employees per hut, this would result in $\sim 9000$ employees. Lufthansa, one of the biggest airlines in Europe, counts 3753 pilots and $\sim 14400$ cabin crew members. In 2005, the World Travel Organization reported $16 \%$ of aircraft passengers being businessmen ( 800 million of the total of 5 billion passengers, but because the number of flights per individual is unknown, there is no exact number of persons exposed). In 1985, there were 27000 mining workers in Bolivia. Thousands of soldiers are exposed to high altitude in Afghanistan $(2500-5000 \mathrm{~m})$, the astronomers of the European South Observatory are working at the Chajnantor plateau at $5320 \mathrm{~m}$, and the athletes and crews of the rally Paris-Dakar, which took place in the Andes thrice, were racing and working up to $5300 \mathrm{~m}$. Many other occupations expose people to hypoxia. Summarized Küpper estimated the total number of employees exposed to any kind of hypoxia exceeding 100 million per year (Küpper, 2006).

Note: From tradition, there are two different approaches to categorize the severity of hypoxia. While any situation at real altitude differentiates 'low altitude' (0-1500 m), 'moderate altitude' (1500-3500 m), 'high altitude' (3500-5300 m), and 'extreme altitude' $(>5300 \mathrm{~m})$, the isobaric hypoxia differs as follows (mainly for technical reasons in fire protection): 20.9-17.0\% (corresponding to $0-1700 \mathrm{~m}$ ), 16.9$14.8 \%$ (corresponding to $1700-2800 \mathrm{~m}$ ), $14.7-13.0 \%$ (corresponding to $2800-3800 \mathrm{~m}$ ), $12.9-10.7 \%$ (corresponding to $3800-5300 \mathrm{~m}$ ), and $<10.7 \%$ (corresponding to $>5300 \mathrm{~m}$ ). Because these systems are well established in the respective user groups, the commission decided to use both unchanged and refer to the 
respective system when specific topics of one or the other are addressed.

\section{OXYGEN, OXYGEN CONCENTRATION, AND OXYGEN PARTIAL PRESSURE-SIMILARITIES AND DIFFERENCES OF THEIR PHYSIOLOGICAL EFFECTS}

While mountaineers traditionally use altitude above sea level as a term to describe the extent of hypoxia, technicians prefer $\% \mathrm{O}_{2}$ (which means oxygen concentration in ambient air at sea level pressure) and physiologists use oxygen partial pressure $\left(\mathrm{pO}_{2}\right)$. The latter is the most accurate term as $\mathrm{pO}_{2}$ is the one and only parameter which is of interest within normal atmospheric conditions, as first explored by Bert (1878), Mosso (1899), and Zuntz et al. (1906) and in 1925, Barcroft for isobaric hypoxia (Barcroft, $1925)$, but both altitude and $\% \mathrm{O}_{2}$ are very closely related to $\mathrm{pO}_{2}$. Although $\% \mathrm{O}_{2}$ and altitude are less exact than $\mathrm{pO}_{2}$, the resulting errors are far too small to have any consequence for occupational medicine. There are some minor physiological differences between isobaric and hypobaric hypoxia [e.g. in pulse frequency and breathing frequency, reviewed in Savourey et al. (2003)], but again these differences are far too small for any clinical consequences. Therefore, the factors can be used equivalently.

For the comparison of $\% \mathrm{O}_{2}$, which may be considered as 'simulated altitude at sea level' to that of 'real' altitude, the term 'corresponding altitude' should be used. The relationship between the parameters is illustrated in Fig. 1 and Table 1. Based on this relationship, the UIAA recommendation presented here provides altitude as the main parameter and $\% \mathrm{O}_{2}$ for isobaric conditions at sea level for technical applications. It should be noted that $\% \mathrm{O}_{2}$ refers to sea level conditions. If an oxygen-reduced atmosphere (isobaric conditions) is created at higher locations, a correction factor according to the respective altitude must be included. Table 1 provides the 'time of useful consciousness', which describes the period of time an unacclimatized person has at the respective oxygen conditions to 'escape' from hypoxia until severe impairment of consciousness or unconsciousness may occur.

It should be noted that there is no direct correlation between the decrease of inspired $\mathrm{pO}_{2}$ and oxygen saturation $\left(\mathrm{SaO}_{2}\right)$. Several studies in the 'classic' area of high-altitude physiology have shown an increase of pulse rate and ventilation (frequency and volume) of $\sim 6$ to $8 \%$ at an altitude of $\sim 2700 \mathrm{~m}$ (e.g. Glaisher, 1862; Bert, 1878; Viault, 1891; Miescher, 1893; Mosso, 1899; Jaquet, 1904; Zuntz et al., 1906), but the sigmoidal form of the oxyhaemoglobin dissocia- tion curve and the later explored so-called 'Bohr effect' (left or right shift of this curve) cause a much lower decrease of $\mathrm{SaO}_{2}$ at low or moderate altitude, where the ascent of the curve is low. Therefore, $\mathrm{SaO}_{2}$ remains at $>90 \%$ in healthy persons at $\sim 3000 \mathrm{~m}$ (Fig. 2) (Küpper, 2006). This also remains constant at low workload (Küpper, 2006). Only if the person is loaded near his/her maximum workload does, pulmonary diffusion becomes a more important limiting factor, which can cause an additional decrease of $\mathrm{SaO}_{2}$ (Küpper, 2006). For the recommendations presented here, the UIAA MedCom has defined the term 'mild hypoxia' as any kind of exposure where $\mathrm{SaO}_{2}$ is $\geq 90 \%$.

\section{PATHOPHYSIOLOGICAL EFFECTS OF HYPOXIA}

It should be emphasized that mild hypoxia is not normally a risk. For any risk estimation, at least a three-dimensional system should be taken into account, which includes independent variables such as altitude and the respective decrease of $\mathrm{pO}_{2}$ and the duration of exposure and dependent variables such as an individuals own risk of symptoms. Several other variables have significant influence on the dependent variable, especially the acclimatization status of the individual. Note: All considerations given below focus on non-acclimatized persons. If a person is completely acclimatized to high altitude, there shouldn't be any risk even at altitude of $\geq 6000 \mathrm{~m}$, if this person is exposed in isobaric conditions to an altitude or hypoxia corresponding to the altitude of acclimatization.

Extreme hypoxia (values $>5000 \mathrm{~m}$ or well $<11 \%$ $\mathrm{O}_{2}$ ) may cause mental impairment up to unconsciousness within half an hour or less. While there is only marginal impairment at $5000 \mathrm{~m}$, this problem increases significantly with increasing altitude as indicated by 'time of useful consciousness' in Table 1 (Amsler, 1971; Ernsting and King, 1994). On the other hand, these data suggest that this hazard does not exist if the person stays well $<5000 \mathrm{~m}$ as most of employees do.

If non-acclimatized persons stay at altitude for several hours or days, altitude-related illnesses may arise. Because symptoms may only arise after $6-8 \mathrm{~h}$ at this altitude - often much later ( $>24 \mathrm{~h})$-most employees will be asymptomatic as they finish their daily work long before that may occur (Bartsch, 1990; Basnyat, 1993; Hackett and Roach, 2001; Maggiorini, 2001; Basnyat and Murdoch, 2003). Nevertheless, especially if sleep at altitude is necessary (e.g. businessmen at high-altitude destinations), this may happen. The risk increases with altitude. Above 2500-3000 m, AMS may occur, while high HAPE is very rare at this altitude [1:4000 nights at $3000 \mathrm{~m}$ (Hochstrasser 

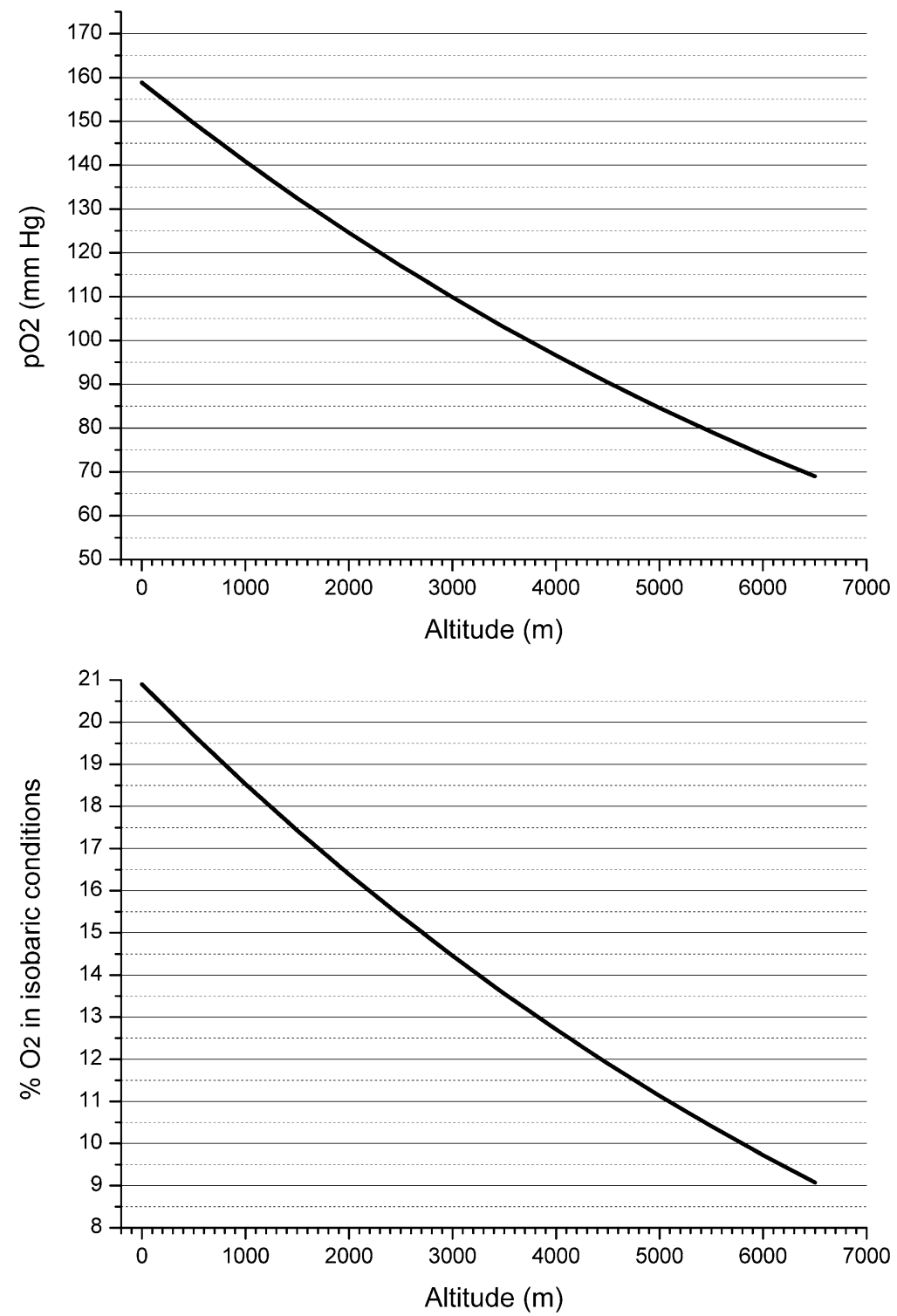

Fig. 1. $\mathrm{pO}_{2}$ and isobaric $\% \mathrm{O}_{2}$ in relation to altitude. Graphs according to ICAO standard atmosphere as given by Ruff and Strughold (1944), Muller (1967), and Ernsting and King (1994) (see also Table 1).

et al., 1986)]. Normally, HAPE does not occur within $<10-36 \mathrm{~h}$ of exposure and well $>4000 \mathrm{~m}$ : if employees arrive by plane at $4500 \mathrm{~m}$, the risk for severe HAPE increases to 1:600 (Hochstrasser et al., 1986), and 30-57\% will suffer from AMS (e.g. Maggiorini et al., 1990; Basnyat et al., 1999; Küpper and Classen, 2002; Savourey et al., 2003; Küpper et al., 2008c; Angelini and Giardini, 2009). On the other hand, these data suggest that some hours or even a night at $3000 \mathrm{~m}$ is relatively safe for unacclimatized but healthy persons. High-altitude cerebral oedema (HACE) happens typically $>5000 \mathrm{~m}$ and much later than AMS or HAPE (onset up to $72 \mathrm{~h}$ of exposure).

After several months of exposure, some people may develop chronic pulmonary hypertension and suffer from signs of insufficiency of the right ventricle (peripheral oedema, dyspnoea, cough, and angina pectoris), which is summarized as 'high-altitude pulmonary hypertension,' (HAPH), formerly called 'subacute mountain sickness'. After years at altitude $>3000$ m, CMS ('Monges Disease') may arise (headache, poor concentration, dizziness, reduced work capacity, 
Table 1. Atmospheric conditions according to ICAO standard atmosphere (Ruff and Strughold, 1944) and the time of useful consciousness for non-acclimatized persons (Amsler, 1971; Ernsting and King, 1994), which can be used to 'escape' from hypoxia if any health problem should arise. Note: There is no limitation of the time of useful consciousness up to $5000 \mathrm{~m}$ or $11.1 \% \mathrm{O}_{2}$, respectively. For corresponding $\mathrm{O}_{2} \%$, see also Fig. 1

\begin{tabular}{|c|c|c|c|c|}
\hline $\begin{array}{l}\text { Corresponding) } \\
\text { Altitude }(\mathrm{m})\end{array}$ & $\begin{array}{l}\text { Atmospheric } \\
\text { pressure } \\
(\mathrm{mm} \mathrm{Hg})\end{array}$ & $\begin{array}{l}\mathrm{pO}_{2} \\
(\mathrm{~mm} \mathrm{Hg})\end{array}$ & $\begin{array}{l}\% \mathrm{O}_{2} \text {, isobaric } \\
\text { conditions, } \\
\text { and sea level }\end{array}$ & $\begin{array}{l}\text { Time of } \\
\text { useful } \\
\text { consciousness }\end{array}$ \\
\hline$\overline{0}$ & 760.0 & 158.8 & 20.9 & No limitation \\
\hline 500 & 716.0 & 149.6 & 19.7 & \\
\hline 1000 & 673.8 & 140.8 & 18.5 & \\
\hline 1500 & 634.0 & 132.5 & 17.4 & \\
\hline 2000 & 596.0 & 124.6 & 16.4 & \\
\hline 2500 & 560.0 & 117.0 & 15.4 & \\
\hline 3000 & 525.8 & 109.9 & 14.5 & \\
\hline 3500 & 493.0 & 103.0 & 13.6 & \\
\hline 4000 & 462.0 & 96.6 & 12.7 & \\
\hline 4500 & 432.6 & 90.4 & 11.9 & \\
\hline 5000 & 404.8 & 84.6 & 11.1 & \\
\hline 5500 & 378.6 & 79.1 & 10.4 & $>30 \mathrm{~min}$ \\
\hline 6000 & 353.6 & 73.9 & 9.7 & \\
\hline 6500 & 330.0 & 69.0 & 9.1 & \\
\hline 7000 & 307.8 & 64.3 & 8.5 & $3-5 \mathrm{~min}$ \\
\hline 10500 & 183.0 & 38.2 & 5.0 & $\sim 1 \mathrm{~min}$ \\
\hline 12900 & 123.5 & 25.8 & 3.4 & $15-30 \mathrm{~s}$ \\
\hline
\end{tabular}

cyanosis, clubbed/drumstick fingers, polycythaemia, and high haemoglobin concentration) (Monge et al., 1992; Arregui et al., 1994; Curran et al., 1997; Moore et al., 1998; Leon-Velarde and Reeves, 1999; Ge and Helun, 2001; Bernardi et al., 2003). Retinal bleeding and other altitude-related problems occur at $>7000 \mathrm{~m}$ only and therefore, these are normally not a topic of occupational medicine.

From several other fields of occupational medicine, it is proven that repeated exposures to moderate hypoxia do not have significant side effects. The biggest group of persons with such an exposure are pilots using small aircrafts without pressurized cabins or artificial oxygen. They are allowed to fly up to $4000 \mathrm{~m}$ and if they stay there as long as the range of the aircraft enables them, some of them complain about fatigue. All other complaints that may be triggered by hypoxia occur at extreme altitude and respective severe hypoxia only (e.g. Küpper and Classen, 2002; Küpper et al., 2008c; Milledge and Küpper, 2008; Angelini and Giardini, 2009).

\section{TYPICAL RISKS OF OCCUPATIONAL EXPOSURE TO HYPOXIC CONDITIONS}

Based on the kinetics of altitude-related symptoms as described above, people at risk can be grouped into four characteristic types of exposure (Fig. 3, Table 2). To do so, five important factors must be taken into account to differentiate the risk profile of exposure to hypoxia:

- Altitude (metre) or equivalent altitude $\left(\% \mathrm{O}_{2}\right)$, respectively

- Duration of exposure

- Altitude profile/acclimatization (intermittent hypoxia included)

- Workload in hypoxic condition

- Native highlanders versus native lowlanders

Individual risks caused by pre-existing conditions will be discussed later [but we also refer to Milledge and Küpper (2008)]. With the five major points given above, at least four kinds of exposure groups can be established (Fig. 3), each with a completely different risk profile.

\section{Extreme short exposure}

Extreme short exposure normally takes place at altitude between 1800 and $2500 \mathrm{~m}$ and for a period of minutes to some hours. The most important kind of occupational exposure is business trips by car (mountain pass) or aircraft but also maintenance work at cable cars, service of ski slopes, or the associated infrastructure like restaurants, etc. Recently, isobaric 
hypoxia of $\sim 17$ to $14.8 \% \mathrm{O}_{2}(+/-0.2)$ is used more and more for the fire prevention of rooms; this exposes another group of personnel to hypoxic conditions corresponding to an altitude of $\sim 1700-2700 \mathrm{~m}$ [based on International Civil Aviation Organization (ICAO) standard atmosphere, Fig. 1]. The duration of exposure here is defined by risk: taking the three-dimensional approach of the risk factors as described above, it is defined as a period which is known to be free of AMS symptoms. As most of the employees are ex-

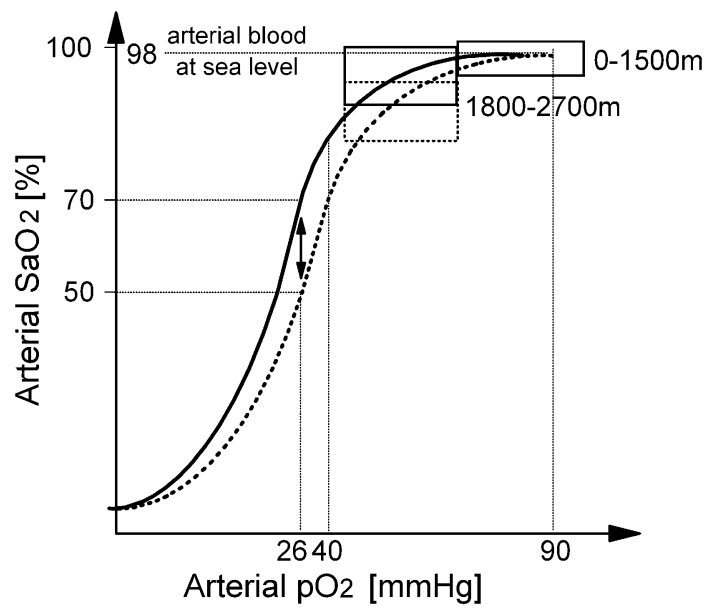

Fig. 2. $\mathrm{SaO}_{2}$ with Bohr effect included: caused by an increase of 2,3-diphosphorglycerate and respiratory alkalosis $\mathrm{SaO}_{2}$ at $2600 \mathrm{~m}$ does not drop to $\sim 85 \%$ as expected without Bohr effect (dotted curve) but only to $\sim 90-95 \%$ (solid curve). At higher altitude with $\mathrm{pO}_{2}$ at $\sim 40 \mathrm{mmHg}$, this effect becomes more important and at extreme altitude, it is the basic principle for survival as it shifts $\mathrm{SaO}_{2}$ from $\sim 50$ to $\sim 70 \%$ [double arrow; data from Hultgren (1997) and Küpper (2006)]. posed to a maximum of $2700 \mathrm{~m}$ or a respective $14.8 \% \mathrm{O}_{2}$, the period of risk is proven to be much $>4 \mathrm{~h}$ and therefore, any employee who spends his/ her lunch break in normoxia will not develop AMS (e.g. Bartsch, 1990; Rabold, 1992; Basnyat, 1993; Bartsch, 1999; Hackett and Roach, 2001; Maggiorini, 2001; Basnyat and Murdoch, 2003; Küpper, 2006).

A total of $\sim 4$ billion aircraft passengers or billions of smokers worldwide, who easily show CO-haemoglobin levels of $10 \%$, are exposed annually to such an extent of hypoxia. This is well within the range of the so-called 'threshold altitude', which is the (corresponding) altitude, where the body shows the first responses to hypoxia. Depending on the system observed, the threshold altitude varies between 1500 (slight increase in pulse rate at rest) to $2400 \mathrm{~m}$ (increase of erythropoietin serum concentration) (Gunga et al., 1994; Sakata et al., 2000). In conclusion, altitudes around the threshold do not cause any risk for healthy people by hypoxia, but they cause a physiological response on the body. It also does not cause risk for people with chronic diseases of moderate severity (Milledge and Küpper, 2008). Severely ill people will be discussed later. The threshold for altitude disease is somewhere $>2500 \mathrm{~m}$ depending on the kind of disease, individual factors, and the duration of exposure. The latter is usually much longer than some hours; therefore, altitude disease should be extraordinary rare in this group of exposure (in contrast to the group of limited exposure, see below).

In some special circumstances, there are some employees exposed to equivalent altitudes between 2700 and $3800 \mathrm{~m}$ in rooms for fire protection. This

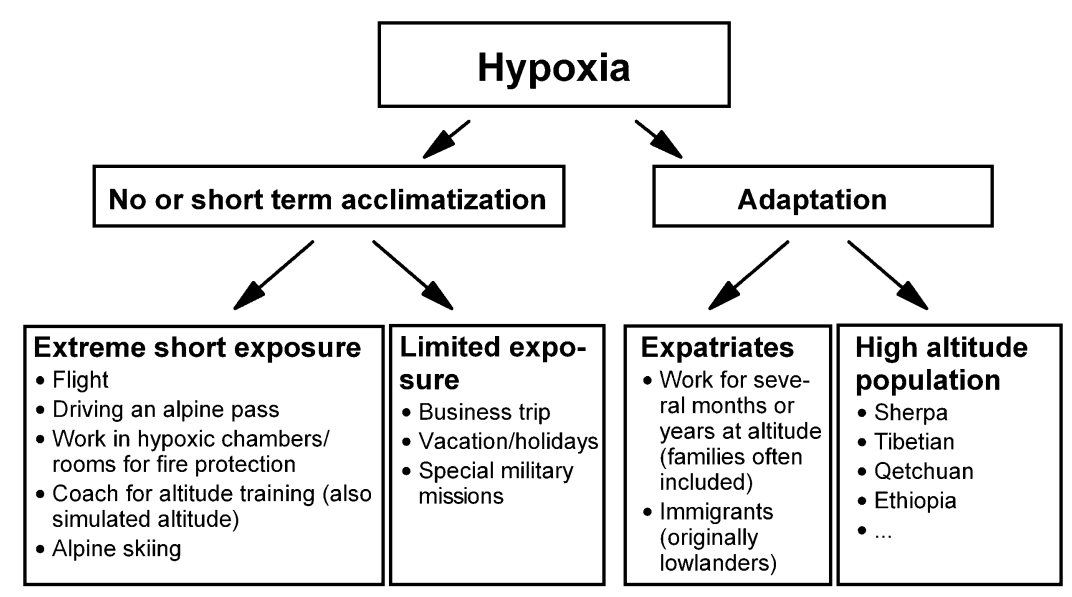

Fig. 3. Different types of occupational exposure to hypoxic conditions (see also Table 2). Note: Because of a multitude of influencing factors (individual, environmental, and work-related), there would be no advantage for occupational medicine if the classification of the types of exposure would be described in more detail or based on individual physiological data. 
Table 2. Characteristics of the types of altitude or hypoxia exposure

\begin{tabular}{|c|c|c|c|}
\hline Group & $\begin{array}{l}\text { Typical (equivalent) } \\
\text { altitude and } \% \mathrm{O}_{2} \\
\text { (isobaric conditions) }\end{array}$ & $\begin{array}{l}\text { Typical } \\
\text { duration of } \\
\text { exposure }\end{array}$ & Typical risk \\
\hline \multirow{3}{*}{$\begin{array}{l}\text { Extreme short } \\
\text { exposure (aircrafts, } \\
\text { cable cars, skiing, road } \\
\text { traffic, and fire } \\
\text { protection rooms) }\end{array}$} & $\begin{array}{l}1800-2600 \mathrm{~m} \\
18-15 \%\end{array}$ & \multirow[t]{3}{*}{$\begin{array}{l}\text { Minutes to } \\
\text { some hours }\end{array}$} & $\begin{array}{l}\text { Pressure changes (persons with infection of the } \\
\text { upper airways) }\end{array}$ \\
\hline & & & $\begin{array}{l}\text { No risk by hypoxia for any person who does not have } \\
\text { severe cardiopulmonary illness }\end{array}$ \\
\hline & $\begin{array}{l}2600-3800 \mathrm{~m} \\
15-13 \%\end{array}$ & & No risk for healthy persons \\
\hline \multirow[t]{2}{*}{ Limited exposure } & \multirow[t]{2}{*}{$2000-3000 \mathrm{~m}$} & \multirow[t]{2}{*}{ Days to weeks } & $\begin{array}{l}\text { AMS if the unacclimatized person sleeps at this } \\
\text { altitude }\end{array}$ \\
\hline & & & $\begin{array}{l}\text { Beside AMS, there is normally no risk to any person } \\
\text { who does not have severe cardiopulmonary illness } \\
\text { (HAPE is extremely rare at this altitude) }\end{array}$ \\
\hline \multirow[t]{3}{*}{ Expatriates } & \multirow[t]{3}{*}{$3000-4500 \mathrm{~m}$} & \multirow[t]{3}{*}{ Years } & HAPH \\
\hline & & & Insufficiency of the right ventricle \\
\hline & & & CMS (Monge's Disease) \\
\hline \multirow[t]{2}{*}{ Altitude populations } & \multirow[t]{2}{*}{$>3000 \mathrm{~m}$} & \multirow[t]{2}{*}{ Several generations } & CMS (see above) \\
\hline & & & Re-entry pulmonary oedema \\
\hline
\end{tabular}

situation is limited by the duration of exposure to a maximum of a few hours, often for $<60 \mathrm{~min}$. As for any room equipped with hypoxia systems for fire protection, these employees can leave immediately at any time and with plenty of time (see Table 1) if they do not feel well. Nevertheless, any break should be spent outside of the hypoxic area (e.g. lunch).

Some common activities expose people to even higher altitude, e.g. skiing at $3800-4000 \mathrm{~m}$ or road or railroad traffic $[\sim 3000 \mathrm{~m}$ (Europe), $\sim 4000 \mathrm{~m}$ (USA and Tibet), and $>5000 \mathrm{~m}$ (South America)]. Here, the main problem may be the change of pressure, especially for children or persons suffering from an infection of the upper airways.

The longest exposure of this type (extreme short exposure) is long distance flights, which could also be classified as 'limited exposure'. Data exist that some airlines operate at an even higher cabin altitude than the limit of $2400 \mathrm{~m}$, which is given by the ICAO regulations, especially when using modern aircraft (Cottrell, 1988).

There is one other small subgroup of people who are a special case: Persons who coach people, normally mountaineers, who pre-acclimatize for extreme altitude expeditions. This is increasingly used, often in facilities that offer isobaric hypoxia. This may expose participants to an altitude of $\geq 5300 \mathrm{~m}$. In most cases, the exposure of employees is limited for some minutes to up to half an hour. With the special advantage of isobaric hypoxia that these employees can easily escape to normal atmospheric conditions at any time if they should feel unwell. People with pre-existing conditions may suffer from severe problems at this altitude while healthy persons should tolerate this exposure well: The duration of exposure is too short to develop AMS and it is also well below the limits of the period after which significant neurological risks may arise (Table 1).

As stated above, the exposure time normally does not exceed a few hours. Up to $3000 \mathrm{~m}$ (and even higher), there is no risk in developing any altitude disease during this period (Rabold, 1992; Basnyat, 1993; Hackett and Roach, 2001; Basnyat and Murdoch, 2003). The main problem for this group may be the acute change of pressure, especially if a person is suffering from the common cold. Normally, everybody-including pregnant women (Jean et al., 2005, 2008) and children (Meijer and Jean, 2008)—will feel well at these altitudes. Exceptions are people with severe pre-existing diseases (see specific paragraph below and Table 3).

With increasing altitude, the maximal workload decreases from -10 to $-15 \%$ per $1000 \mathrm{~m}$ of altitude (beginning at $1500 \mathrm{~m}$ above sea level) with highly trained people loosing the most power (Fig. 4) (Kuhne, 1877; Bert, 1878; Loeb, 1896; Zuntz et al., 1906; Buskirk et al., 1966, 1967; Jackson and Sharkey, 1988; West, 1990; Küpper, 2006). Since most work performed at altitude is of limited load on the human body [estimated $0.5-1.0 \mathrm{~W} \mathrm{~kg}{ }^{-1}$ body weight, (Küpper, 2006)], this effect does not limit most of the previously described activities at altitude. During very demanding or exhausting work at $>3000 \mathrm{~m}, \mathrm{O}_{2}$ diffusion and reduced contact time of the erythrocytes in the pulmonary capillaries create more limiting factors for people doing intense work as they 
cannot stabilize their $\mathrm{SaO}_{2}$ at a level which can be expected for the respective altitude (Küpper, 2006). As a result, their $\mathrm{SaO}_{2}$ will decrease. Working conditions like these are exclusively for healthy people (Küpper, 2006) and even then the limited (decreased) workload must be taken into account when the required activity and the resources are planned (Fig. 4). If possible, only well acclimatized persons should perform such a work.

\section{Limited exposure}

The typical exposure of the 'limited exposure group' is $2000-3000 \mathrm{~m}$ for a few days or weeks.

Table 3. Examples for permanent or temporary contraindications for altitude sojourns of the 'extreme short exposure group' or 'limited exposure group' as defined above (Milledge and Küpper, 2008) [according to the recommendations for aircraft travellers (Siedenburg, 2009)]

\begin{tabular}{ll}
\hline Diagnosis & $\begin{array}{l}\text { Period for } \\
\text { which altitude/hypoxia } \\
\text { should be avoided }\end{array}$ \\
\hline $\begin{array}{l}\text { Stroke } \\
\text { Myocardial } \\
\text { infarction }\end{array}$ & $\begin{array}{l}3 \text { months } \\
6 \text { weeks, if no complications } \\
10 \text { weeks (or more) in the } \\
\text { case of complications } \\
\text { (e.g. significant arrhythmia) }\end{array}$ \\
$\begin{array}{l}\text { Aortocoronary } \\
\text { bypass operation }\end{array}$ & $\begin{array}{l}\text { 2-3 weeks } \\
\text { Percutaneous transluminal } \\
\text { coronary angioplasty }\end{array}$ \\
$\begin{array}{l}\text { Stent } \\
\begin{array}{l}\text { Pace maker } \\
\text { implantation }\end{array}\end{array}$ & 3 days \\
$\begin{array}{l}\text { Acute broncho-pulmonary } \\
\text { infections }\end{array}$ & $\begin{array}{l}\text { After a check for correct } \\
\text { function is ok }\end{array}$ \\
$\begin{array}{l}\text { Asthma (stress } \\
\text { induced) }\end{array}$ & No exposure until recovery \\
\hline
\end{tabular}

At some places, these people will be exposed to even higher conditions of 4000-5000 m, e.g. at Colorado or South America. Examples of locations for businessmen or normal travellers (not mountaineers) are given in Fig. 5.

In contrast to the 'extreme short exposure group', the combination of altitude and duration of exposure can potentially cause altitude-related diseases (AMS). An increase of the pulse rate for $\sim 12$ to $14 \%$ should be expected at 2500-3000 m (e.g. Glaisher, 1862; Muller, 1967). A comparable increase of minute ventilation and breathing frequency will occur (Rupwate et al., 1990). Oxygen saturation will decrease only for $\sim 6$ to $8 \%$ of the saturation measured at sea level and be stable at 90-94\% (Horii et al., 1994; Cottrell et al., 1995). A slight decrease of aerobic performance (without significant effect on performance at work) must be expected at $3000 \mathrm{~m}$ (Fig. 4), but no significant effect on psychomotoric functions (Tune, 1964; Waanders and Riedmann, 1994). There are some data, which indicate a slight impairment in the coordination of complex movements, especially when they have to be performed very quickly.

The main risk for the limited exposure group is the development of altitude diseases, most often AMS. HAPE) is extremely rare at this altitude [1:4000 nights at $3000 \mathrm{~m}$ (Hochstrasser et al., 1986)] as it normally occurs $>4000 \mathrm{~m}$. A significantly increased risk exists for any person who had a rapid ascent profile, e.g. businessmen arriving by aircraft at high-altitude destinations like La Paz. If the arrival destination is $\sim 4500 \mathrm{~m}$, the risk for HAPE with severe symptoms increases to 1:600 (Hochstrasser et al., 1986) [signs for HAPE in X-ray up to $31.7 \%$ (Bircher et al., 1994)] and 30-57\% will suffer from AMS (Hackett

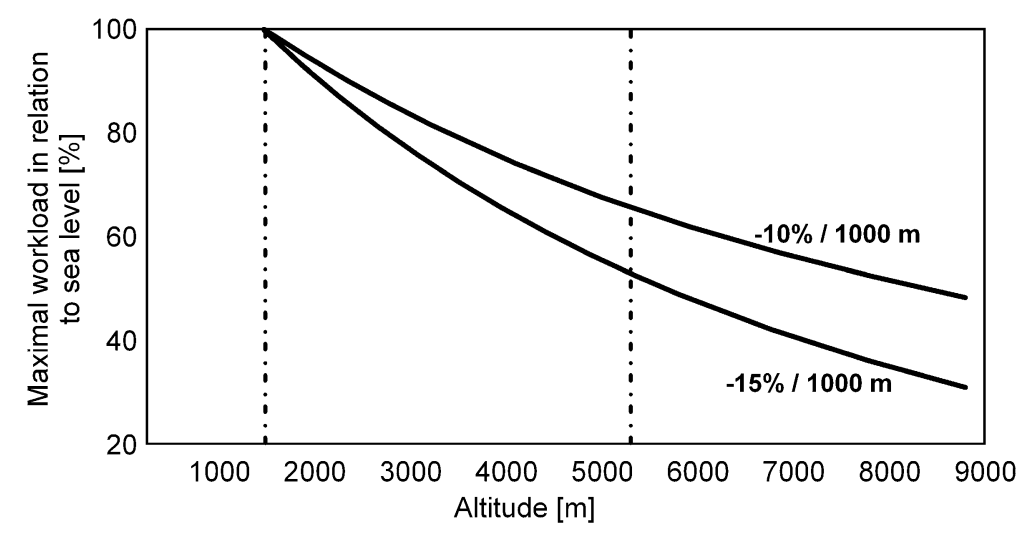

Fig. 4. Decrease in maximal workload at altitude (Buskirk et al., 1966; Buskirk et al., 1967; Jackson and Sharkey, 1988; West, 1990; Küpper, 2006). At above $7500 \mathrm{~m}$, the maximal workload is decreased in such an extent that rescue of a stranded person is impossible in most cases. $1500 \mathrm{~m}$ : 'threshold altitude'; $5300 \mathrm{~m}$ : limit of complete acclimatization/permanent stay. 


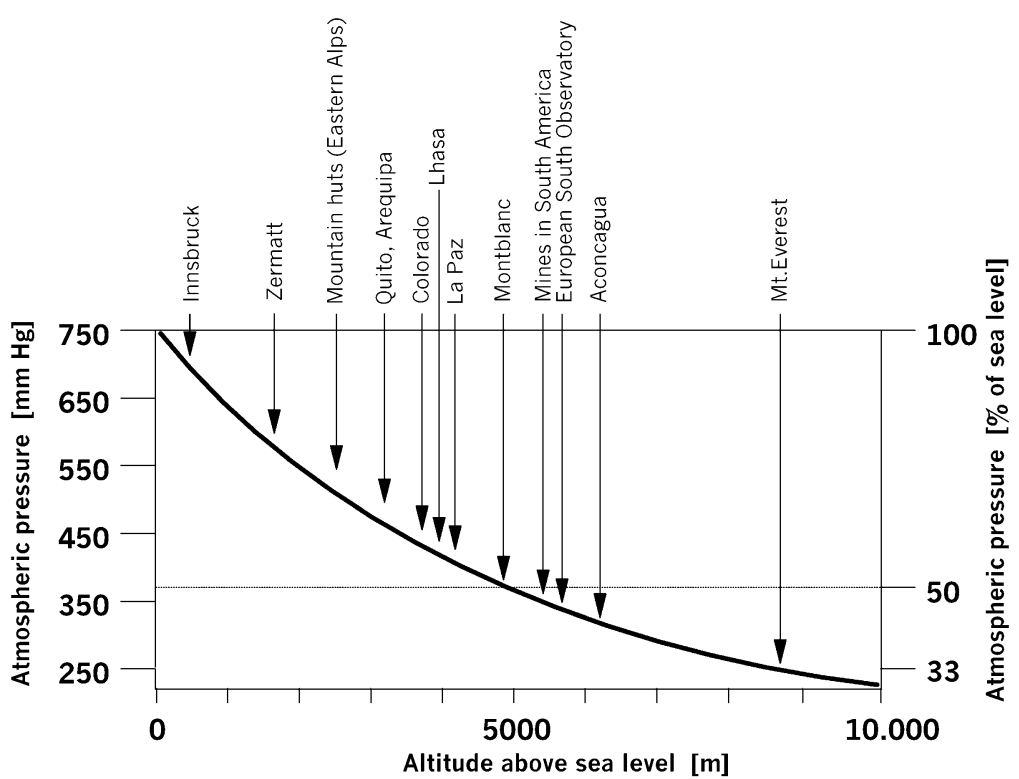

Fig. 5. Examples for destinations of businessmen or normal travellers. Note: Some working places e.g. at mines in South America are higher than the highest mountains in the European Alps.

and Rennie, 1979; Maggiorini et al., 1990; Basnyat, 1993; Basnyat et al., 1999; Schneider et al., 2002). On the other hand, these data indicate that some hours or even a night at $3000 \mathrm{~m}$ is relatively safe, at least for healthy people. Some people with pre-existing diseases may be at specific risk (Milledge and Küpper, 2008). Nevertheless, any strategy for occupational health and safety for the limited exposure group has to focus on AMS.

\section{Expatriates and immigrants}

Expatriates and immigrants in this paper are defined as persons who migrate as lowlanders to highaltitude regions, normally $>3000 \mathrm{~m}$. Some of them are living $>4500 \mathrm{~m}$. The duration may be for several months but is frequently for years. Normally, this group will not suffer from acute altitude diseases as they are acclimatized completely except during the first day after arrival if the arrival was characterized by 'too fast too high'.

In many cases, the employees are attended by their families. As a consequence, pregnancy may be a problem (Jean et al., 2008) and more often children of different age will be exposed to high altitude. After a while they may suffer from specific diseases of the cardiopulmonary system: HAPH (formerly called subacute mountain sickness) with acute bouts of high blood pressure in the pulmonary vessels (Sui et al., 1988) and high-altitude heart disease. For details, see Meijer and Jean (2008).
After some months at high-altitude, adults may develop the symptoms of subacute mountain sickness. Caused by chronic pulmonary hypertension, these patients suffer from signs of insufficiency of the right ventricle (peripheral oedema, dyspnoea, cough, and angina pectoris). After years at altitude, CMS (Monge's Disease) may arise (headache, poor concentration, dizziness, reduced work capacity, cyanosis, clubbed/drumstick fingers, polycythaemia, and high haemoglobin concentration) (Monge et al., 1992; Arregui et al., 1994; Curran et al., 1997; Moore et al., 1998; Leon-Velarde and Reeves, 1999; Ge and Helun, 2001; Bernardi et al., 2003).

\section{Altitude populations}

Altitude populations are defined as populations living for several generations (some for $>30000$ years) at altitude $>3000 \mathrm{~m}$. These people show long-term and genetic adaptations. Most health problems are not altitude related but caused by socio-economic factors [e.g. chronic bronchitis, Kangri carcinoma (skin cancer in cicatrice caused by multiple burning either by carrying a small oven heated with charcoal (kang) under the coat or by sleeping around a fire and burning the belly when the person turns around during sleep) etc.]. While altitude-related health disorders are very uncommon in Tibetians and occupational medicine is not yet established in Ethiopia, South American highlanders - many of them working in mines-have been studied and are of special interest here. Some 
of them may develop CMS (see above). Another specific problem is re-entry pulmonary oedema where highlanders and also expatriates or immigrants who visit friends or relatives near sea level are of special risk when they return home at high altitude. The symptoms are the same as that for HAPE.

Note: In contrast to the belief of most Westerners, many porters in the Himalayans are not true Sherpas anymore and are immigrant or expatriate lowlanders! They may suffer from the same altitude-related risks as any other visitor (Basnyat and Litch, 1997).

\section{PROBLEMS WITH PRESENT GUIDANCE}

Up until now, there was no single guidance worldwide which took into account the multidimensional specificities of hypoxia exposure. Some papers are based on guidelines established for mining or work in storage tanks, silos, reaction vessels, enclosed drains, or sewers, for fire or explosions (e.g. HSE, 2005). These papers assume that the 'lack of oxygen' causes danger. All guidelines ignore that there is no risk for altitude disease when the duration of exposure is limited for some minutes or hours (e.g. FPA, 2005; HSE, 2005; Bilzon and Stokes, 2008) and most workers have finished their work long before this may happen (Bartsch, 1990; Basnyat, 1993; Hackett and Roach, 2001; Maggiorini, 2001; Basnyat and Murdoch, 2003). Things become critical when the science is misinterpreted within these papers: concentration of oxygen $<16 \%$ does not lead to unconsciousness and death (HSENI, 1999). This may be true for extreme hypoxia well $<10.5 \%$ or $5500 \mathrm{~m}$ but not for $16 \%$ as stated in HSENI (1999) (see also Table 2).

Some recommendations state that HAPE or HACE 'could be particularly problematic' (Bilzon and Stokes, 2008), which $>140$ years of altitude research proves to be incorrect. Interestingly, the same report includes the statement that ' $\ldots$ it is unlikely that working in conditions of 13-15\% oxygen represents a meaningful risk' [chapter 2.6.6 in Bilzon and Stokes (2008)]. The recommendation to use self-containing breathing apparatuses at oxygen concentrations of $13-15 \%$ would result in nearly exact the amount of additional oxygen which is needed to carry the $16.8 \mathrm{~kg}$ equipment and to breath through its mask. A medical examination is suggested to exclude pre-existing diseases and special investigations are recommended if pathologies were found in the screening. Although not referenced, the latter mainly follow international guidelines, such as Milledge and Küpper (2008). It is interesting, that the authors also mention possible health benefits of longterm work in hypoxic conditions as some recent papers about hypoxia training indicate (e.g. Boyer and Blume,
1984; Rose et al., 1988; Kayser, 1992, 1994; Armellini et al., 1997; Schobersberger et al., 2003; Haufe et al., 2008; Netzer et al., 2008).

Other reports clearly state that there is no increased risk for employees in a 17-15\% low oxygen atmosphere environment (FPA, 2005). Consequently, it is recommended to perform health assessments only for individuals who will be working and performing full time strenuous work in a $15 \%$ low oxygen atmosphere environment and full time work in a $13 \%$ low oxygen atmosphere environment. The health assessment is not necessary if the oxygen concentration will be $17 \%$, where the exposure will be $<2 \mathrm{~h} \mathrm{day}^{-1}$ (FPA, 2005).

The Austrian and German Governments (Huke et al., 2005) require a medical check for any person working at $<17 \%$, while the Swiss regulations do so at $<18 \%$ (SUVA, 2009). Analysed in detail, the German regulation (Huke et al., 2005) is not an official recommendation (just an internal letter for the ministry) and shows lack of knowledge about the physiology of hypoxia. Therefore, some recommendations derived from Huke et al. (2005), such as Angerer and Nowak (2003), include the same problems. From the viewpoint of physiology, the U.S. recommendations given by OSHA, which apply for confined spaces and not just for hypoxia, have strange implications. If any atmosphere with $<19 \%$ $\mathrm{O}_{2}$ is life threatening, as stated in these papers, humans could not live in many parts of the USA and American businessmen visiting Europe should do so by ship, because they would not survive the flight (OSHA, 1993a, b).

There is no guidance worldwide, which takes into account whether a person is able to 'escape' from hypoxia at any time or not for the risk assessment. With this aspect, a businessperson arriving at a high-altitude destination like La Paz is significantly more at risk than a maintenance worker in a room with hypoxia for fire protection.

It is surprising that nobody brought to the attention of the authors when the several national guidelines were established that high performance tasks like piloting an aircraft is allowed up to $4000 \mathrm{~m}(13000 \mathrm{ft}$, equivalent to $97 \mathrm{~mm} \mathrm{Hg}$ of $\mathrm{pO}_{2}$ or $12.5 \% \mathrm{O}_{2}$ ) without a pressurized cabin or supplemental oxygen in most countries of the world (in some of them even higher, e.g. South America). The whole discussion is dominated by (fictive) risk assumptions, while some data suggest that intermittent hypoxia of moderate degree also has some benefit instead of risk for persons who are regular exposed as there are an amelioration of the lipid profile, insulin resistance, leptin, body weight, and others (e.g. Boyer and Blume, 1984; Azevedo 
et al., 1995; Armellini et al., 1997; Grosfeld et al., 2002; Schobersberger et al., 2003; Simler et al., 2006; Yingzhong et al., 2006; Netzer et al., 2008). In conclusion, a more detailed specialized analysis of the individual exposure is necessary to provide adequate advice for health and safety.

\section{ASPECTS OF OCCUPATIONAL SAFETY AND HEALTH}

In contrast to any other occupational exposure where less exposure normally means less risk, employees at altitude benefit if they are exposed as often as possible to hypoxia because a partial adaptation can be expected, although scientific data about intermittent hypoxia are limited (Richalet et al., 1992; Beidleman et al., 2004; Jones et al., 2006; Muza et al., 2006). Comparisons between the several studies are also limited because of the altitude profiles; the duration of exposure and the normoxic phases between exposures are different; and the studies prove that repetitive exposure to hypoxia increases acclimatization and decreases the risk for AMS. In most cases, the hypoxic exposure was equivalent to an altitude of $4000 \mathrm{~m}$, but the duration per day and the total period of exposure were very different ( $\geq 3 \mathrm{~h} \mathrm{day}^{-1}$ for 6-20 days) (Levine et al., 1992; Richalet et al., 1992; Beidleman et al., 2004; Jones et al., 2006; Muza et al., 2006; Katayama et al., 2007). Even short exposures $2-4 \mathrm{~h}$ are expected to have some effect on acclimatization (Burtscher et al., 2008). This corresponds to findings in physiology and molecular biology which proved effects of intermittent hypoxia with simulated altitude for hypoxic ventilatory drive, hyperventilation, and arterial oxygen saturation (Levine et al., 1992; Richalet et al., 1992; Garcia et al., 2000a; Garcia et al., 2000b; Bernardi et al., 2001a; Bernardi et al., 2001b; Beidleman et al., 2004; Jones et al., 2006; Lusina et al., 2006; Muza et al., 2006) or for hypoxia inducible factor alpha (HIF-1 $\alpha$ ), 2,3-diphosphorglycerate, and others (Chilov et al., 1999; Richard et al., 1999; Hofer et al., 2001; Heinicke et al., 2002) during several hours. A detailed survey about this topic is given in (Küpper and Schoffl, 2009).

All persons working at altitude or in hypoxic conditions should be advised to drink enough to keep their fluid balance stable. Note: In contrast to common medical thinking, it is not the heart, which carries the greatest risk for people at altitude. While the myocardium is able to handle astonishing degrees of hypoxia, the lung may be the limiting factor in the case of a pre-existing disease (Milledge and Küpper, 2008).

\section{Extreme short exposure}

As mentioned above, the situation for this group may be best illustrated by the situation inside an aircraft's cabin (this excludes very high workload subjects and coaching of athletes who acclimatize to extreme altitudes, see below). In this
- Vital capacity

- FEV1

- $\mathrm{SaO}_{2}$

- $\mathrm{pO}_{2}$ art
- 31

- $70 \%$

- $85 \%$

- $70 \mathrm{mmHg}$ well-studied situation, there are the following minimum requirements given by aviation medicine (values for sea level in adults) (Siedenburg, 2009):

Haemoglobin should be $>10 \mathrm{~g} \mathrm{dl}^{-1}$ and erythrocyte count $>3$ million $\mu^{-1}$ (Siedenburg, 2009), but strictly spoken, this focuses an acute loss of blood while both are relative contraindications in the case of a chronically anaemic fully compensated patient who may be completely adapted.

For exposure up to $2700 \mathrm{~m}$ or $14.8 \% \mathrm{O}_{2}$, a checkup by occupational medicine is considered to be necessary only in cases, if the worker is obviously unfit. Only very severe cardiopulmonary diseases [New York Heart Association (NYHA) stages IIIIV, (N.N., 1994)] would exclude the person from occupational exposure to hypoxia (Milledge and Küpper, 2008) and this situation is easily identifiable by others as these patients will suffer from significant shortness of breath after climbing one floor and normally they appear unfit for any work. If in doubt, the person who supervises the respective work and the employee may send the unfit person to occupational medicine before he or she enters a hypoxic environment. This also includes business people who are due to visit high-altitude destinations.

On the other hand, if the employee performs any aerobic endurance sport regularly and without problems, there is no doubt-without any other medical investigation-that there is no risk if this person is exposed within the conditions as described for the 'extreme short exposure group' up to $2700 \mathrm{~m}$ or $\sim 15$ to $14.8 \% \mathrm{O}_{2}$. Laboratory or technical investigations by occupational medicine are only required in 
cases, which are not completely clear as described above. These should include:

- Significant anaemia: blood status

- exclude sickle cell anaemia if the person belongs to a group where this is endemic

- Pulmonary hypertension: echocardiography - Pulmonary disease: spirometry and ergometry

- Cardiac disease: ergometry, (stress) echocardiography

If a person is not perfectly fit, this does not necessarily exclude this employee from work in hypoxia, but then a more careful fitness check should be performed and the expected workload estimated, e.g. according to (Spitzer et al., 1982). For employees with a body mass index within normal range, a minimum fitness of $75 \mathrm{~W}$ is considered to be sufficient for any work without additional workload, e.g. pure supervising, while a minimum of $125 \mathrm{~W}$ is recommended for low intensity activity and $200 \mathrm{~W}$ for high intensity work (e.g. carrying heavy loads) [Spitzer et al., 1982; Küpper et al., 2009]. For standardized environmental conditions like hypoxic rooms, the procedure for occupational health and safety as given in Fig. 6 can be simplified to the flowchart given in Fig. 7.

If employees are exposed to equivalent altitudes of 2700-3800 m (14.8-13\% $\mathrm{O}_{2}$, respectively), a consultation with a physician for occupational medicine and with experience or training in hypoxia or altitude medicine is mandatory (Küpper et al., 2009, 2010). The medical check should include:

- The employee's medical history:

- Any indicators for cardiopulmonary diseases or for significant limitations of maximum workload? (Sports?)

- Any significant disease or surgery in the last year?

$\circ$ Any problems during altitude sojourns in the past?

$\circ$ High or extreme workload at altitude expected?

- Red blood cell count

- Ergometry

- Spirometry

As $\mathrm{VO}_{2} \mathrm{max}$ is the limiting factor at high altitude, ergometry and spirometry may be combined as spiroergometry. Due to the loss of work capacity at altitude (e.g. in isobaric hypoxia), a higher minimum fitness is necessary at sea level. A total of $100 \mathrm{~W}$ are considered to be sufficient for supervising or similar activities, $150 \mathrm{~W}$ for low intensity, and $200 \mathrm{~W}$ for high intensity work (Spitzer et al., 1982; Küpper et al., 2009, 2010). For employees working with no or low workloads in isobaric environment, a break of 15 min every $2 \mathrm{~h}$ in a normoxic environment is recommended (which, of course, is impossible for work at real altitude). For high intensity activities, there should be a break in normoxic conditions for 30 min every 2 h (Küpper et al., 2009, 2010).

Employees who go $>3800 \mathrm{~m}$ (respectively work at $<13.8 \% \mathrm{O}_{2}$ ) should be checked as mentioned in the previous section. For $3800-5300 \mathrm{~m}$, the minimal workload at sea level should be $125 \mathrm{~W}$ for supervision or similar tasks and $200 \mathrm{~W}$ for low intensive work (Spitzer et al., 1982; Küpper et al., 2009). High intensive work is for fully trained and acclimatized people only and without any cardiopulmonary disease (Küpper et al., 2009, 2010). For supervision, a break of 15 min every $2 \mathrm{~h}$ in normoxic conditions is sufficient, but for any higher workload, it should be extended to 30 min (Küpper et al., 2009, 2010).

Any exposure $>5300 \mathrm{~m}$ or at $<10.7 \% \mathrm{O}_{2}$ requires completely acclimatized and fully trained employees without any cardiopulmonary disease for any expected workload. The significant decrease of work capacity ( $\sim 50 \%$ compared to normoxia or respective sea level!) should be taken into account when planning such tasks. At altitudes, which are normally visited for extreme short duration (1500-3000 m), the maximal workload is only marginal impaired (Fig. 4). Therefore, the recommendations given for demanding work (e.g. in Spitzer et al., 1982) can be used without modification. Above that the reduction of $10 \%$ workload per each $1000 \mathrm{~m}$, above $1500 \mathrm{~m}$ should be added to the minimal requirements, e.g.:

If a minimal requirement for a certain work at sea level is estimated as $2 \mathrm{~W} \mathrm{~kg}^{-1}$ body weight and this work shall be done at $4000 \mathrm{~m}$, the estimation is as follows:

$$
\begin{aligned}
&(4000-1500) / 1000=2.5 ; 2.5 * 10 \%=25 \% ; \\
& 2 \mathrm{~W} / \mathrm{kg}+25 \%=2.5 \mathrm{~W} / \mathrm{kg} .
\end{aligned}
$$

At sea level, this employee must be able to provide at least $2.5 \mathrm{~W} \mathrm{~kg}^{-1}$ to be able to do the respective work at $4000 \mathrm{~m}$.

Since hypoxic chambers are increasingly available (e.g. rooms or training centres for hypoxia training), employees who shall be exposed to $<12.9 \%$ or $>3800 \mathrm{~m}$ should be exposed to well-controlled hypoxia once before their exposure at work. The exposure must take into account the kind of work and the expected duration and especially the (equivalent) altitude $\left(\mathrm{pO}_{2}\right)$ of the exposure during work: for a task to be 


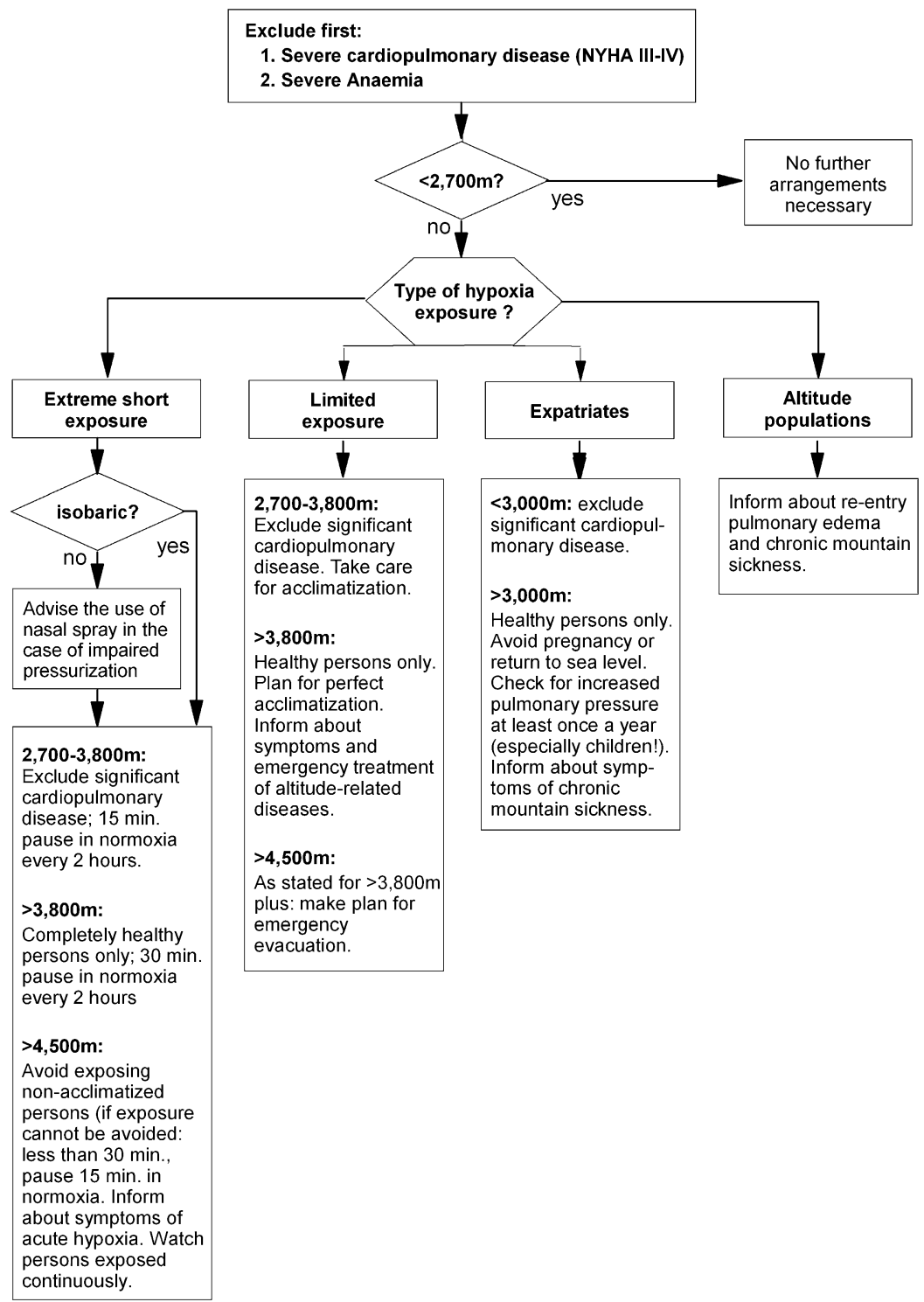

Fig. 6. Occupational health and safety for work in hypoxia.

performed in a controlled environment (hypoxic rooms) for a limited duration, an acute exposure for $1-2 \mathrm{~h}$ at the (equivalent) altitude where the work will be performed later should be sufficient. During exposure, the person should be monitored for $\mathrm{SaO}_{2}$, pulse rate, and altitude-related symptoms by persons with adequate skills in altitude medicine and supervised by a physician. Persons with cardiopulmonary diseases $>$ NYHA I, anaemic or pregnant persons should not be chosen for work at high altitude or hypoxia which corresponds to $>3800 \mathrm{~m}$ or $<13 \% \mathrm{O}_{2}$ (Küpper, 2005; Jean et al., 2008; Milledge and Küpper, 2008).
Any employee should be advised to leave hypoxic areas if he/she feels unwell. Retreating to a normoxic area as soon as possible is the most effective therapy in such a situation. As altitude-related diseases never start suddenly, any employee will have plenty of time to leave hypoxia (see also Table 2). It is not necessary to have a stand-by 'rescue team'. If the symptoms recover completely after $1 / 4-1 / 2 \mathrm{~h}$, the person can re-enter, if necessary. If the subject does not recover within $1 / 2 \mathrm{~h}$, he/she should be advised to consult a physician who is a specialist in altitude medicine and occupational medicine before the next exposure. 


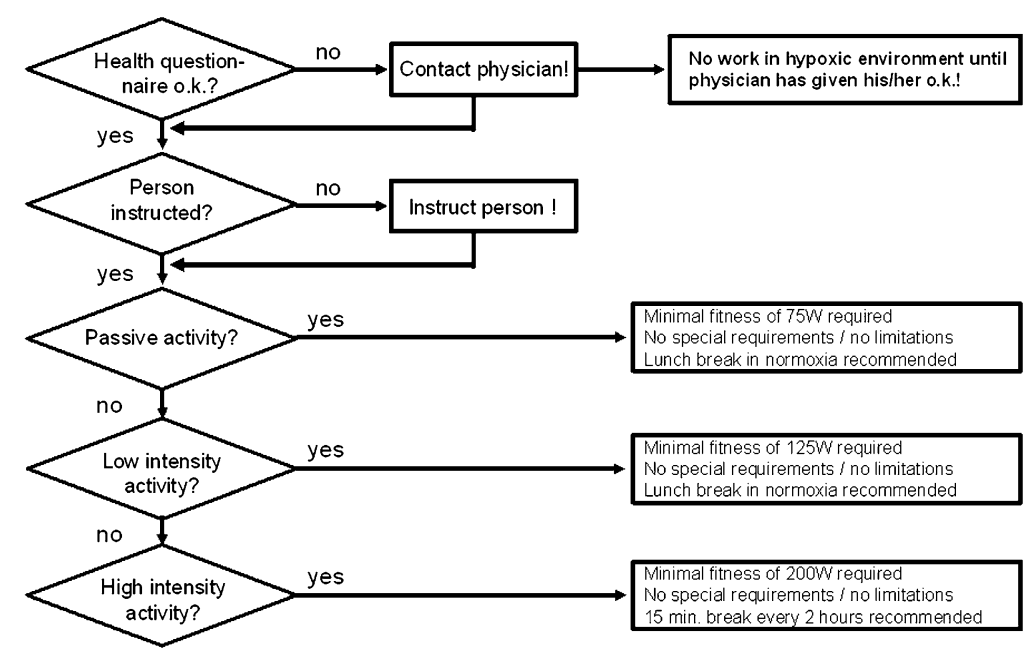

Fig. 7. Flowchart for occupational health and safety for standardized conditions at $16.9-14.8 \% \mathrm{O}_{2}$ or $1700-2700$ above sea level [Küpper et al., 2009].

If the employee cannot escape for any reason at $>3800 \mathrm{~m}$ (e.g. work in remote regions at high altitude or overnight stay of unacclimatized businessmen at high destinations), an oxygen bottle and a mask with reservoir balloon (e.g. Venturi mask) may be added to the first aid equipment and at least one person of the team must get the instructions on how to use this equipment. A device for immediate and easy communication with a doctor or rescue team (radio, mobile phone, etc.) is recommended.

People with fairly advanced pre-existing conditions need detailed analysis of their actual health status before entering hypoxic environments. Those with cardiopulmonary diseases are of special interest. According to stages specified by the Criteria Committee of the NYHA, the following limitations for any exposure should be considered (NYHA, 1928, 1994; Miller-Davis et al., 2006):

- NYHA I (no symptoms): no limitations at altitude, except high intensive activity at high altitude $(>3800 \mathrm{~m})$

- NYHA II (symptoms during moderate workload): no limitations at altitude for activities of minor workload, take caution at $>3800 \mathrm{~m}$ or $<13 \% \mathrm{O}_{2}$.

- NYHA III-IV (symptoms during minimal workload or at rest): contraindication for altitude. Diagnoses and situations, which are a permanent or temporary contraindication, are given in Table 2. We also refer to the recommendations given in (Milledge and Küpper, 2008).
Persons with pulmonary hypertension should avoid altitude or hypoxia, at least for overnight stays. Table 3 gives an overview about some important permanent or temporary contraindications for hypoxia exposure. For details about several other pre-existing conditions and individual risks (diseases, pregnancy, children, etc.) at altitude, see also Jean et al. (2005, 2008), Meijer and Jean (2008), Milledge and Küpper (2008), and Angelini and Giardini (2009).

Facilities for training and acclimatization, which typically expose employees (and clients) to $>4500 \mathrm{~m}$ should consider a safety concept during construction. At extreme altitude or severe hypoxia, the persons exposed should be observed for safety by a 'rescue person' who is outside the isobaric hypoxia but in permanent contact to the person(s) inside. For optimum supervision rooms, isobaric hypoxia should be constructed with a big window to the next room. Above $4500 \mathrm{~m}$, safety may be further increased if an oxygen bottle and a mask is available. Above $4500 \mathrm{~m}$, a specialized high-altitude physician should be on call. Above $5000 \mathrm{~m}$, he/she should be on scene.

Employees working in extreme conditions need to be educated about symptoms and management of acute hypoxia. Again, if they work regularly in such conditions (e.g. every day $2-3 \times$ for $15-60 \mathrm{~min}$ or even more) a benefit by partial acclimatization can be expected (although data are not yet sufficient to recommend details).

\section{Limited exposure}

As this group goes to comparable altitude as the 'extreme short exposure group', the minimal 
requirements of the cardiopulmonary system and the exclusion criteria (Table 3) are the same (Milledge and Küpper, 2008). Special attention should be paid to persons who might be suspected for obstructive sleep apnoea as this is often combined with pulmonary hypertension. The later will increase significantly at altitude. As mentioned above, AMS is a risk for this group, which cannot yet be predicted sufficiently by any medical investigation. Here, preventive occupational medicine includes detailed advice about the symptoms of AMS and how to treat them (Küpper et al., 2008a). If possible, those persons who are responsible for the management of the specific work should be contacted to provide such information and an adequate ascent profile should be included in the plans. This may include an extra day on arrival and an overnight stay at intermediate altitude. If an immediate ascent and overnight stay $>2500 \mathrm{~m}$ cannot be avoided, prophylaxis with drugs may be considered [acetazolamide $125 \mathrm{mg}$ bid (Basnyat et al., 2003; Bartsch et al., 2004; Küpper et al., 2008a)].

It should be mentioned here that some facilities, where people work at high altitude, provide oxygenenriched rooms (e.g. some mines or telescopes in the Andes). Every additional 1\% of oxygen corresponds to a 'reduction' of $300 \mathrm{~m}$ of altitude without increasing the risk of fire (at least within a wide range). With this technology, some facilities provide an interior environment, which corresponds to $3000 \mathrm{~m}$, which is well tolerated.

If the person will be exposed without having the chance to escape from hypoxia (e.g. business trips to destinations at high altitude), an ascent profile according to international recommendations (e.g. (Küpper et al., 2008a) should be an integral part of the strategy when the respective work is planned. If the place of work is situated $>3800 \mathrm{~m}$, the person should sleep at least one night under controlled conditions (hypobaric room at a training centre with physicians experienced in altitude medicine) at the respective equivalent altitude before his/her first departure to such places. Depending on the final altitude, this may include several nights in hypobaric conditions to realize an altitude profile and acclimatization according to the 'Gold Standard' as recommended (Küpper et al., 2008a).

Employees should be advised to contact an experienced high-altitude physician in the event that he/she does not feel well at high altitude and cannot descend. Painkillers, nifedipine, dexametasone, and acetazolamide and information on how to contact the physician to manage an emergency should be given to him/her before departure for any destination $>3800 \mathrm{~m}$. Below $3800 \mathrm{~m}$, a standard painkiller (no aspirin at altitude!) should be sufficient (Küpper et al., 2008a). For some destinations, where portable hyperbaric chambers are available, the employees should be instructed in detail how to use them safely (Küpper et al., 2008b).

\section{Expatriates and immigrants}

This group should be informed about AMS as described above. Before they leave, they should get a more detailed medical examination, especially with electrocardiography and echocardiography included. This aims at two topics: (i) to exclude pulmonary hypertension and (ii) to get initial values for a comparison with later controls. Subacute altitude disease, the main risk for this group, causes a hypertrophy and dilatation of the right ventricle, a pulmonary hypertension, and sometimes a pericardial effusion. In many places where these expatriates work there will be no possibility for echocardiography. In this situation, a follow-up investigation may be performed during a holiday trip home or similar convenient time. A control echocardiography should be performed at least once a year or if symptoms arise. Note that accompanying children need special attention (Meijer and Jean, 2008). If any pathologies, which indicate increased pulmonary pressure or right ventricle hypertrophy or dilatation, are found at echocardiography, the patients should be advised to leave their high-altitude residency as soon as possible.

\section{Altitude populations}

As mentioned above, altitude-related problems are rare in this group. Employees descending from altitude for holidays or for other reasons for more than a week should be advised to avoid re-entry HAPE. They should also be trained in First Aid if a HAPE should occur, especially in the use of oxygen an Nifedipin or - if available - in the use of a portable hyperbaric chamber (Küpper et al., 2008a, b).

South American highlanders should be surveyed by occupational medicine for CMS. As a minimum, these checks should include an analysis of haematocrit, haemoglobin, and erythrocyte cell count and should be performed annually. If symptoms arise which suggest CMS additional echocardiography should be performed, if possible.

Acknowledgements - The authors want to give a warm 'thank you' to everyone at the UIAA Medical Commission who has contributed to the consensus statement presented here. Members of the commission are: C. Angelini (Italy), B.B. (Nepal), J. Bogg (Sweden), A.R. Chioconi (Argentina), S. Ferrandis (Spain), U.G. (Germany), U.H. (Switzerland), D.H. (UK), J. Holmgren (Sweden), M. Horii (Japan), D. Jean (France), A. Koukoutsi (Greece), J.K. (Czech Republic), T.K. 
(Germany), H. Meijer (The Netherlands), J.S.M. (UK), A. Morrison (UK), H. Mosaedian (Iran), S. Omori (Japan), I. Rotman (Czech Republic), V.S. (Germany), J. Shahbazi (Iran), and J. Windsor (UK). The recommendation was approved by written consent in lieu of a meeting in August 2009.

\section{REFERENCES}

Amsler HA. (1971) Flugmedizin für zivile Besatzungen. Bern, Switzerland: Verlag Eidgenössisches Luftamt.

Angelini C, Giardini GConsensus statement of the UIAA medical commission vol. 16: travel to altitude with neurological disorders. Bern, Switzerland. Available at: www. theuiaa.org/medical_advice.html. Accessed 25 November 2010.

Angerer P, Nowak D. (2003) Working in permanent hypoxia for fire protection-impact on health. Int Arch Occup Environ Health; 76: 87-102.

Armellini F, Zamboni M, Robbi R et al. (1997) The effects of high altitude trekking on body composition and resting metabolic rate. Horm Metab Res; 29: 458-61.

Arregui A, Leon-Velarde F, Cabrera J et al. (1994) Migraine, polycythemia and chronic mountain sickness. Cephalalgia; 14: $339-41$.

Azevedo JL, Jr., Carey JO, Pories WJ et al. (1995) Hypoxia stimulates glucose transport in insulin-resistant human skeletal muscle. Diabetes; 44: 695-8.

Barcroft J. (1925) Respiratory function of the blood. Part I. New York, NY: Cambridge University Press.

Bartsch P. (1990) Das Höhenlungenödem: Epidemiologie, Klinik, Pathogenese und Therapie. In: Jenny E and Flora G, editors. Jahrbuch 1990. Innsbruck, Austria: Österreichische Gesellschaft für Alpin- und Höhenmedizin; pp. 78-91.

Bartsch P. (1999) Aktuelle Aspekte der Höhenmedizin. In: Jenny E, Riedmann G and Flora G, editors. Jahrbuch 1999 der Österreichischen Gesellschaft für Alpin- und Höhenmedizin. Innsbruck, Austria: Österreichische Gesellschaft für Alpin- und Höhenmedizin; pp. 99-108.

Bartsch P, Bailey DM, Berger MM et al. (2004) Acute mountain sickness: controversies and advances. High Alt Med Biol; 5: 110-24.

Basnyat B. (1993) Acute mountain sickness in local pilgrims to a high altitude lake (4154 m) in Nepal. J Wild Med; 4: 286-92.

Basnyat B, Gertsch JH, Johnson EW et al. (2003) Efficacy of lowdose acetazolamide (125 mg BID) for the prophylaxis of acute mountain sickness: a prospective, double-blind, randomized, placebo-controlled trial. High Alt Med Biol; 4: 45-52.

Basnyat B, Lemaster J, Litch JA. (1999) Everest or bust: a cross sectional, epidemiological study of acute mountain sickness at 4243 meters in the Himalayas. Aviat Space Environ Med; 70: 867-73.

Basnyat B, Litch JA. (1997) Medical problems of porters and trekkers in the Nepal Himalaya. Wilderness Environ Med; 8: 78-81.

Basnyat B, Murdoch DR. (2003) High-altitude illness. Lancet; 361: 1967-74.

Beidleman BA, Muza SR, Fulco CS et al. (2004) Intermittent altitude exposures reduce acute mountain sickness at $4300 \mathrm{~m}$. Clin Sci (Lond); 106: 321-8.

Bernardi L, Passino C, Serebrovskaya Z et al. (2001a) Respiratory and cardiovascular adaptations to progressive hypoxia; effect of interval hypoxic training. Eur Heart J; 22: 879-86.

Bernardi L, Passino C, Wilmerding V et al. (2001b) Breathing patterns and cardiovascular autonomic modulation during hypoxia induced by simulated altitude. J Hypertens; 19: 947-58.

Bernardi L, Roach RC, Keyl C et al. (2003) Ventilation, autonomic function, sleep and erythropoietin. Chronic mountain sickness of Andean natives. Adv Exp Med Biol; 543: 161-75.

Bert P. (1878) La pression barométrique. Paris, France: Masson. Bilzon JLJ, Stokes K. (2008) Health and safety issues surrounding working in a reduced oxygen (hypoxic) environment. Bath, UK: Department for Sport, Health and Exercise, University of Bath.

Bircher HP, Eichenberger U, Maggiorini M et al. (1994) Relationship of mountain sickness to physical fitness and exercise intensity during ascent. J Wild Med; 5: 302-11.

Boyer SJ, Blume FD. (1984) Weight loss and changes in body composition at high altitude. J Appl Physiol; 57: 1580-5.

Burtscher M, Gatterer H, Faulhaber M. (2008) Vorakklimatisation durch intermittierende Hypoxie. In: Haditsch B, Domej W, Schobersberger W, et al. Jahrbuch 2008 der Östereichischen Gesellschaft für Alpin-und Höhenmedizin. Innsbruck, Austria: Österreichische Gesellschaft für Alpin- und Höhenmedizin; pp. 45-56.

Buskirk ER, Kollias J, Akers RF et al. (1967) Maximal performance at altitude and on return from altitude in conditioned runners. J Appl Physiol; 23: 259-67.

Buskirk ER, Kollias J, Picon Reategui E. (1966) Physiology and performance of track athlets at various altitudes in the United States and Peru. In: Goddard RF, editor. The international symposium on the effects of altitude on physical performance. Chicago, IL: The Athletic Institute.

Chilov D, Camenisch G, Kvietikova I et al. (1999) Induction and nuclear translocation of hypoxia-inducible factor-1 (HIF-1): heterodimerization with ARNT is not necessary for nuclear accumulation of HIF-1alpha. J Cell Sci; 112: 1203-12.

Cottrell JJ. (1988) Altitude exposures during aircraft flight. Flying higher. Chest; 93: 81-4.

Cottrell JJ, Lebovitz BL, Fennell RG et al. (1995) Inflight arterial saturation: continuous monitoring by pulse oximetry. Aviat Space Environ Med; 66: 126-30.

Curran LS, Zhuang J, Sun SF et al. (1997) Ventilation and hypoxic ventilatory responsiveness in Chinese-Tibetan residents at 3,658 m. J Appl Physiol; 83: 2098-104.

Ernsting J, King P. (1994) Aviation medicine. 2nd edn. Oxford, UK: Butterworth-Heinemann Ltd.

FPA. (2005) Low oxygen atmospheres and the risk control of associated health hazards. Moreton-in-Marsh, UK: The Fire Protection Association.

Garcia N, Hopkins SR, Powell FL. (2000a) Effects of intermittent hypoxia on the isocapnic hypoxic ventilatory response and erythropoiesis in humans. Respir Physiol; 123: 39-49.

Garcia N, Hopkins SR, Powell FL. (2000b) Intermittent vs continuous hypoxia: effects on ventilation and erythropoiesis in humans. Wilderness Environ Med; 11: 172-9.

Ge RL, Helun G. (2001) Current concept of chronic mountain sickness: pulmonary hypertension-related high-altitude heart disease. Wilderness Environ Med; 12: 190-4.

Glaisher J. (1862) Notes of effects experienced during recent balloon ascents. Lancet; 2: 559-60.

Grosfeld A, Andre J, Hauguel-De Mouzon S et al. (2002) Hypoxia-inducible factor 1 transactivates the human leptin gene promoter. J Biol Chem; 277: 42953-7.

Gunga HC, Kirsch K, Rocker L et al. (1994) Time course of erythropoietin, triiodothyronine, thyroxine, and thyroidstimulating hormone at 2,315 m. J Appl Physiol; 76: 1068-72. 
Hackett PH, Rennie D. (1979) Rales, peripheral edema, retinal hemorrhage and acute mountain sickness. Am J Med; 67: 214-8.

Hackett PH, Roach RC. (2001) High-altitude illness. N Engl J Med; 345: 107-14.

Haufe S, Wiesner S, Engeli S et al. (2008) Influences of normobaric hypoxia training on metabolic risk markers in human subjects. Med Sci Sports Exerc; 40: 1939-44.

Heinicke H, Hofer T, Wenger RH et al. (2002) Die zelluläre Antwort auf Sauerstoffmangel. Dtsch Z Sportmed; 53: $270-6$.

Hochstrasser J, Nanzer A, Oelz O. (1986) [Altitude edema in the Swiss Alps. Observations on the incidence and clinical course in 50 patients 1980-1984]. Schweiz Med Wochenschr; 116: 866-73.

Hofer T, Desbaillets I, Hopfl G et al. (2001) Dissecting hypoxia-dependent and hypoxia-independent steps in the HIF-1alpha activation cascade: implications for HIF-1alpha gene therapy. FASEB J; 15: 2715-7.

Horii M, Higashi H, Kitajima M et al. (1994) Physiological characteristics of middle-aged high-altitude climbers of a mountain iver $8000 \mathrm{~m}$ in height. $\mathrm{J}$ Wild Med; 5: $447-450$

HSE. (2005) Work in confined spaces. London, UK: Health and Safety Executive.

HSENI. (1999) Approved code of practice-safe work in confined spaces. Belfast, UK: Health and Safety Executive for Northern Ireland.

Huke M, Heger M, Jansing P et al. (2005) Handlungsanleitung für die Beurteilung von Arbeiten in sauerstoffreduzierter Atmosphäre für die Arbeitsschutzverwaltungen der Länder LV 38 [Operational guidelines for the evaluation of work in oxygen reduced atmosphere for the Departments for Occupational Health and Safety of the federal states]. publ.: Bayerisches Staatsministerium für Gesundheit, Ernährung und Verbraucherschutz. Report No.: LV 38. München, Germany: Länderausschuss für Arbeitsschutz und Sicherheitstechnik. Available at lasi.osha.de/docs/lv38.pdf. Accessed 25 November 2010.

Hultgren H. (1997) High altitude medicine. Stanford, CA: Hultgren Publications.

Jackson CG, Sharkey BJ. (1988) Altitude, training and human performance. Sports Med; 6: 279-84.

Jaquet A. (1904) Ueber die physiologische Wirkung des Hoehenklimas. Basel, Switzerland: Universitäts-Buchdruckerei Friedrich Reinhardt.

Jean D, Leal C, Kriemler S et al. (2005) Medical recommendations for women going to altitude. High Alt Med Biol; 6: 22-31.

Jean D, Leal C, Meijer H. (2008) Consensus statement of the UIAA medical commission Vol. 12: women going to altitude. Bern, Switzerland Available at www.theuiaa.org/ medical_advice.html. Accessed 25 November 2010.

Jones J, Muza S, Fulco C et al. (2006) Normobaric intermittent hypoxic exposure improve foot march performance at 4300m (Abstract). High Alt Med Biol; 4: 333.

Katayama K, Sato K, Hotta N et al. (2007) Intermittent hypoxia does not increase exercise ventilation at simulated moderate altitude. Int J Sports Med; 28: 480-7.

Kayser B. (1992) Nutrition and high altitude exposure. Int J Sports Med; 13: 129-32.

Kayser B. (1994) Nutrition and energetics of exercise at altitude. Theory and possible practical implications. Sports Med; 17: 309-32.

Kuhne W. (1877) Die Bedeutung des Sauerstoffs für die vitale Bewegung. Ztschr Biologie; 36: 425-522.
Küpper T. (2005) [Non-traumatic aspects of sport climbing]. Wien Med Wochenschr; 155: 163-70.

Küpper T. (2006) [Workload and professional requirements for alpine rescue]. Professoral thesis at Aachen Technical University/Germany, 2006 (English publication in preparation) [Professoral Thesis (English publication in preparation)]. Aachen, Germany: Aachen Technical University.

Küpper T, Classen J. (2002) Single epileptic seizures provoked by high altitude. J Travel Med; 9: 94-6.

Küpper T, Gieseler U, Angelini C et al. (2008a) Consensus statement of the UIAA medical commission vol. 2: emergency field management of acute mountain sickness, high altitude pulmonary oedema, and high altitude cerebral Oedema. Bern, Switzerland Available at www.theuiaa.org/ medical_advice.html. Accessed 25 November 2010.

Küpper T, Gieseler U, Milledge J. (2008b) Consensus statement of the UIAA medical commission Vol. 3: portable hyperbaric chambers. Bern, Switzerland Available at www.theuiaa.org/ medical_advice.html. Accessed 25 November 2010.

Küpper T, Milledge JS, Hillebrandt D et al. (2009) Consensus statement of the UIAA medical commission Vol. 15: work in hypoxic conditions. Bern, Switzerland (update 2010). Available at www.theuiaa.org/medical_advice.html. Accessed 25 November 2010.

Küpper T, Schoffl V, Netzer N. (2008c) Cheyne stokes breathing at high altitude: a helpful response or a troublemaker? Sleep Breath; 12: 123-7.

Küpper TE, Schoffl V. (2009) Preacclimatization in hypoxic chambers for high altitude sojourns. Sleep Breath; 14: 187-191.

Leon-Velarde F, Reeves JT. (1999) International consensus group on chronic mountain sickness. Adv Exp Med Biol; 474: 351-3.

Levine BD, Friedman DB, Engfred K et al. (1992) The effect of normoxic or hypobaric hypoxic endurance training on the hypoxic ventilatory response. Med Sci Sports Exerc; 24: $769-75$.

Loeb J. (1896) Untersuchungen über die physiologischen Wirkungen des Sauerstoffmangels. Pflügers Arch; 62: 249-94.

Lusina SJ, Kennedy PM, Inglis JT et al. (2006) Long-term intermittent hypoxia increases sympathetic activity and chemosensitivity during acute hypoxia in humans. J Physiol; 575: 961-70.

Maggiorini M. (2001) Trekking und Höhenaufenthalt. Ther Umsch; 58: 387-93.

Maggiorini M, Buhler B, Walter M et al. (1990) Prevalence of acute mountain sickness in the Swiss Alps. BMJ; 301: 853-5.

Meijer HJ, Jean D. (2008) Consensus statement of the UIAA medical commission Vol. 9: children at altitude. Bern, Switzerland Available at www.theuiaa.org/medical_advice. html.

Miescher M. (1893) Ueber die Beziehungen zwischen Meereshöhe und Beschaffenheit des Blutes. Korrespondenzbl Schweizer Ärzte; 23: 809-30.

Milledge J, Küpper T. (2008) Consensus statement of the UIAA medical commission Vol. 13: people with pre-existing conditions going to the mountains. Bern, Switzerland Available at www.theuiaa.org/medical_advice.html.

Miller-Davis C, Marden S, Leidy NK. (2006) The New York heart association classes and functional status: what are we really measuring? Heart Lung; 35: 217-24.

Monge CC, Arregui A, Leon-Velarde F. (1992) Pathophysiology and epidemiology of chronic mountain sickness. Int J Sports Med; 13 (Suppl. 1): S79-81. 
Moore LG, Niermeyer S, Zamudio S. (1998) Human adaptation to high altitude: regional and life-cycle perspectives. Am J Phys Anthropol;107 (Suppl. 27): 25-64.

Mosso A. (1899) Der Mensch auf den Hochalpen. Leipzig, Germany: Verlag von Veit \& Comp.

Muller B. (1967) Die gesamte Luftfahrt- und Raumflugmedizin. Düsseldorf, Germany: Droste Verlag.

Muza S, Fulco C, Beidleman B et al. (2006) Normobaric intermittent hypoxic exposure decrease AMS at $4300 \mathrm{~m}$ altitude (Abstract). High Alt Med Biol; 4: 338.

Netzer NC, Chytra R, Küpper T. (2008) Low intense physical exercise in normobaric hypoxia leads to more weight loss in obese people than low intense physical exercise in normobaric sham hypoxia. Sleep Breath; 12: 129-34.

NYHA. (1928) Diseases of the heart and blood vessels: nomenclature and criteria for diagnosis. Criteria Committee of the New York Heart Association. 6th edn. Boston, MA: Little Brown.

NYHA. (1994) Nomenclature and criteria for diagnosis of diseases of the heart and great vessels. Criteria Committee of the New York Heart Association. 9th edn. Boston, MA: Little, Brown \& Co; pp. 253-56.

OSHA. (1993a) Confined Space Standard No.29 CFR 1910.146. Report No.: 29 CFR 1910.146. Washington, DC: Occupational Safety \& Health Administration. Available at http://www.osha.gov/pls/oshaweb/owadisp. show_document?p_table $=$ STANDARDS\&p_id $=9797$. Accessed 25 November 2010.

OSHA. (1993b) Respiratory Protection Standard No.29 CFR 1910.134. Report No.: No.29 CFR 1910.134. Washington, DC: Occupational Safety \& Health Administration. Available at http://www.osha.gov/pls/oshaweb/owadisp.show document?p_table $=$ STANDARDS\&p_id $=12716$. Accessed 25 November 2010.

Rabold MB. (1992) Dexamethasone for prophylaxis and treatment of acute mountain sickness. J Wilderness Med; 3: $54-60$.

Richalet JP, Bittel J, Herry JP et al. (1992) Use of a hypobaric chamber for pre-acclimatization before climbing Mount Everest. Int J Sports Med; 13 (Suppl. 1): S216-20.

Richard DE, Berra E, Gothie E et al. (1999) p42/p44 mitogenactivated protein kinases phosphorylate hypoxia-inducible factor 1alpha (HIF-1alpha) and enhance the transcriptional activity of HIF-1. J Biol Chem; 274: 32631-7.

Rose MS, Houston CS, Fulco CS et al. (1988) Operation Everest. II: nutrition and body composition. J Appl Physiol; 65: 2545-51.

Ruff S, Strughold H. (1944) Grundriss der Luftfahrtmedizin. 2. Aufl. ed. Leipzig, Germany: Johann Ambrosius Barth.
Rupwate RU, Chitaley M, Kamat SR. (1990) Cardiopulmonary functional changes in acute acclimatisation to high altitude in mountaineers. Eur J Epidemiol; 6: 266-72.

Sakata S, Shimizu S, Kishi T et al. (2000) Correlation between erythropoietin and lactate in humans during altitude exposure. Jpn J Physiol; 50: 285-8.

Savourey G, Launay JC, Besnard Y et al. (2003) Normo- and hypobaric hypoxia: are there any physiological differences? Eur J Appl Physiol; 89: 122-6.

Schneider M, Bernasch D, Weymann J et al. (2002) Acute mountain sickness: influence of susceptibility, preexposure, and ascent rate. Med Sci Sports Exerc; 34: 1886-91.

Schobersberger W, Schmid P, Lechleitner M et al. (2003) Austrian Moderate Altitude Study 2000 (AMAS 2000). The effects of moderate altitude $(1,700 \mathrm{~m})$ on cardiovascular and metabolic variables in patients with metabolic syndrome. Eur J Appl Physiol; 88: 506-14.

Siedenburg J. (2009) Kompendium Reisemedizin und Flugmedizin. 6. Aufl. ed. Norderstedt, Germany: BoD—Books on Demand.

Simler N, Grosfeld A, Peinnequin A et al. (2006) Leptin receptor-deficient obese Zucker rats reduce their food intake in response to hypobaric hypoxia. Am J Physiol Endocrinol Metab; 290: E591-7.

Spitzer H, Hettinger T, Kaminski G. (1982) Tafeln für den Energieumsatz bei körperlicher Arbeit. Berlin, Germany: Beuth Verlag.

Sui GJ, Liu YH, Cheng XS et al. (1988) Subacute infantile mountain sickness. J Pathol; 155: 161-70.

SUVA. (2009) Arbeiten in sauerstoffreduzierter Atmosphäre [Work in oxygen reduced atmosphere]. Luzern, Switzerland: Schweizer Unfallversicherungsanstalt.

Tune GS. (1964) Psychological effects of hypoxia: review of certain literature from the period 1950 to 1963 . Percept Mot Skills; 19: 551-62.

Viault F. (1891) Sur la quantité d'oxygène contenue dans le sang des animaux des hauts plateaux de l'Amerique du Sud. Comptes Rendus Acad Sci (Paris); 112: 295-8.

Waanders R, Riedmann G. (1994) Short term impairment in cognitive functioning after a rapid ascent to altitude of 4,559 meters (Abstract). Eur J Neurisci (Suppl); 7: 217.

West JB. (1990) Limiting factors for exercise at extreme altitudes. Clin Physiol; 10: 265-72.

Yingzhong Y, Droma Y, Rili G et al. (2006) Regulation of body weight by leptin, with special reference to hypoxia-induced regulation. Intern Med; 45: 941-6.

Zuntz N, Loewy A, Müller Fet al. (1906) Höhenklima und Bergwanderungen in ihrer Wirkung auf den Menschen. Berlin, Germany: Deutsches Verlagshaus Bong \& Co. 